\title{
Multiple linear regression and random forest to predict and map soil properties using data from portable X-ray fluorescence spectrometer ( $p X R F$ )
}

\section{Regressão linear múltipla e random forest para predição e mapeamento de atributos do solo utilizando dados de espectrômetro portátil de fluorescência de raios-X (pXRF)}

\author{
Sérgio Henrique Godinho Silva ${ }^{1 *}$, Anita Fernanda dos Santos Teixeiraa ${ }^{1}$, Michele Duarte de Menezes ${ }^{1}$, \\ Luiz Roberto Guimarães Guilherme' ${ }^{1}$, Fatima Maria de Souza Moreira ${ }^{1}$, Nilton Curi'
}

'Universidade Federal de Lavras/UFLA, Departamento de Ciência do Solo/DCS, Lavras, MG, Brasil

*Corresponding author: sergio.silva@dcs.ufla.br

Received in April 9, 2017 and approved in June 22, 2017

\begin{abstract}
Determination of soil properties helps in the correct management of soil fertility. The portable X-ray fluorescence spectrometer (pXRF) has been recently adopted to determine total chemical element contents in soils, allowing soil property inferences. However, these studies are still scarce in Brazil and other countries. The objectives of this work were to predict soil properties using pXRF data, comparing stepwise multiple linear regression (SMLR) and random forest (RF) methods, as well as mapping and validating soil properties. 120 soil samples were collected at three depths and submitted to laboratory analyses. pXRF was used in the samples and total element contents were determined. From pXRF data, SMLR and RF were used to predict soil laboratory results, reflecting soil properties, and the models were validated. The best method was used to spatialize soil properties. Using SMLR, models had high values of $\mathrm{R}^{2}(\geq 0.8)$, however the highest accuracy was obtained in RF modeling. Exchangeable $\mathrm{Ca}, \mathrm{Al}, \mathrm{Mg}$, potential and effective cation exchange capacity, soil organic matter, pH, and base saturation had adequate adjustment and accurate predictions with RF. Eight out of the 10 soil properties predicted by RF using pXRF data had $\mathrm{CaO}$ as the most important variable helping predictions, followed by $\mathrm{P}_{2} \mathrm{O}_{5^{\prime}} \mathrm{Zn}$ and $\mathrm{Cr}$. Maps generated using RF from pXRF data had high accuracy for six soil properties, reaching $\mathrm{R}^{2}$ up to 0.83 . pXRF in association with RF can be used to predict soil properties with high accuracy at low cost and time, besides providing variables aiding digital soil mapping.
\end{abstract}

Index terms: Soil analyses; spatial prediction; proximal sensor.

\begin{abstract}
RESUMO
A determinação de atributos do solo auxilia no correto manejo da sua fertilidade. O equipamento portátil de fluorescência de raios-X (pXRF) foi recentemente adotado para determinar o teor total de elementos químicos em solos, permitindo inferências sobre atributos do solo. No entanto, esses estudos ainda são escassos no Brasil e em outros países. Os objetivos deste trabalho foram prever atributos do solo a partir de dados do pXRF, comparando-se os métodos de regressão linear múltipla stepwise (SMLR) e de random forest (RF), além de mapear e validar atributos do solo. 120 amostras de solo foram coletadas em três profundidades e submetidas a análises laboratoriais. Utilizou-se o pXRF para leitura das amostras e determinou-se o teor total de elementos. A partir dos dados do pXRF, foram utilizadas SMLR e RF para predizer resultados laboratoriais, que refletem atributos do solo, e os modelos foram validados. O melhor método foi utilizado para espacializar os atributos do solo. Utilizando $S M L R$, os modelos apresentaram valores elevados de $\mathrm{R}^{2}(\geq 0,8)$, porém maior acurácia foi obtida na modelagem com RF. A capacidade de troca de cátions potencial e efetiva, matéria orgânica do solo, pH, saturação por bases e teores trocáveis de $\mathrm{Ca}$, Al e Mg apresentaram ajustes adequados e predições acuradas com RF. Dos dez atributos do solo preditos por RF a partir de dados do pXRF, sete apresentavam $\mathrm{CaO}$ como a variável mais importante para auxiliar as predições, seguido por $\mathrm{P}_{2} \mathrm{O}_{5^{\prime}}$ Zn e Cr. Os mapas gerados a partir de dados do pXRF usando RF apresentaram adequados valores de $\mathrm{R}^{2}$ para seis atributos do solo, atingindo $\mathrm{R}^{2}$ de até 0,83 . O pXRF em associação com RF pode ser usado para prever atributos do solo com elevada acurácia, com rapidez e a baixo custo, além de proporcionar variáveis que auxiliam o mapeamento digital de solos.
\end{abstract}

Termos para indexação: Análises de solo; predição espacial; sensor próximo.

\section{INTRODUCTION}

Soils present diverse physical, chemical, mineralogical and biological properties, which influence their diverse potentialities of use (Birkeland, 1999; Resende et al., 2014; Schaetzl; Anderson, 2005), such as plant growth. The characterization of those properties is of great importance for the proper management and conservation of soils (Severiano et al., 2009). For that, several laboratory analyses of different levels of complexity are employed, which helps making decisions on the correct management required according to the needs of the crops, so that the agricultural production may be increased (Lopes; Guilherme, 2016). 
On the other hand, carrying out laboratory tests in a large number of samples requires more time and financial resources, as well as chemical reagents, which generate residues. Thus, the use of tools that quickly allow the evaluation of soil properties, at low cost and without residues production may facilitate the evaluation of more samples to characterize soils in more detail and for different purposes.

Portable X-ray fluorescence spectrometer (pXRF) is a tool used in works of several fields of study for identification and quantification of chemical elements present in varied materials (Ioannides et al., 2016; Milić, 2014; Peinado et al., 2010; Rouillon; Taylor, 2016; Terra et al., 2014; Zhu; Weindorf; Zhang, 2011). This equipment emits high-energy X-ray beams, which cause the displacement of electrons from inner to outer orbits as they hit the atoms of the elements in the sample. In sequence, the displaced electrons return to their original orbits emitting a fluorescence characteristic of each chemical element, as it is related to the element atomic number. Thus, in a few seconds the equipment is able to determine the total contents of elements of the Periodic Table between $\mathrm{Mg}$ and $\mathrm{U}$, allowing its use both in the field and in the laboratory (Weindorf; Bakr; Zhu, 2014).

The $\mathrm{pXRF}$ generates a large data set, which may slow down their analyses and interpretation in detail. In this sense, the use of machine learning tools may accelerate the identification of data for characterizing soils. Several methods of analyzing large amount of data of both continuous and categorical variables have been used in works of various natures, such as the stepwise multiple linear regression (SMLR) (Juhos; Szabó; Ladányi, 2015; Menezes et al., 2016; Rodrigues; Corá; Fernandes, 2012). This analysis adjusts regression models from easily obtained variables to estimate data more difficult to be acquired, in which the addition or removal of predictive variables to the model is performed based on statistical tests, generating a final equation. Weindorf et al. (2012) evaluated the pXRF to discriminate spodic and albic horizons in the field, using SMLR to estimate organic carbon data from pXRF data, concluding that the equipment was adequate, contributing to the rapid generation of chemical data.

Another method that has been increasingly used for predictions is the so-called random forest (RF) (Breiman, 2001). This algorithm presents as advantages the possibility of using both numerical and categorical variables, modeling non-linear relationships, assessment of the importance of each variable for the generation of the final model, calculation of modeling errors, among others (Breiman,
2001; Liaw; Wiener, 2002). However, despite of classifying the variables according to their importance to the model (Archer; Kimes, 2008), this method does not generate a final equation of the model, as opposed to SMLR. Therefore, it is sometimes referred to as a black-box method (Grimm et al., 2008), although some works have pointed out that this method is robust and provides better results than other methods for both spatial and non-spatial predictions (Hengl et al., 2015; Lies; Glaser; Huwe, 2012; Souza et al., 2016).

In recent years, most works involving digital soil mapping has been based on continuous variables for the area of interest, such as satellite images and digital elevation models and their derivatives (e.g. slope, topographic wetness index, curvatures, etc.), to spatialize soils information (Adhikari et al., 2014; Giasson et al., 2015; Menezes et al., 2014; Silva et al., 2016a; TaghizadehMehrjardi et al., 2015). However, when working in smaller areas, mainly in developing countries, it is common to face difficulties in obtaining data with high spatial resolution, which tends to make the use of these variables unfeasible. In this sense, pXRF can be an alternative to obtain a large amount of punctual data that, after being spatialized, may contribute to spatial predictions (Silva et al., 2016b).

In spite of the advantages of using $\mathrm{pXRF}$ to analyze elemental composition of materials, very few works have used pXRF in Brazil and in other developing countries for studies with a variety of purposes, mainly regarding soils. In this sense, due to the search for methods to obtain soils information in rapid and economical ways, the objectives of this work were: (i) to predict results of laboratory analysis through SMLR and RF from data generated by pXRF, validating the generated models and; (ii) to evaluate the potential of $\mathrm{pXRF}$ to aid spatial prediction of analytical results, reflecting soil properties, generating and validating maps of soil properties.

\section{MATERIAL AND METHODS}

\section{Study area}

This work was carried out at Santa Luzia Farm, in the county of Campos Altos, Minas Gerais, Brazil, located between latitudes $19^{\circ} 35^{\prime} 05.33^{\prime \prime}$ and $19^{\circ} 35^{\prime} 17.80^{\prime \prime} \mathrm{S}$ and longitudes $46^{\circ} 16^{\prime} 14.46^{\prime \prime}$ and $46^{\circ} 15^{\prime} 24.34^{\prime \prime} \mathrm{W}$, covering 17.1 ha. The climate of the region is Aw, with annual average rainfall of 1,450 mm (Motta; Baruqui; Santos, 2004), dry winters and rainy summers, and monthly average temperature greater than $18{ }^{\circ} \mathrm{C}$ in all months of the year. The area has varying land uses, such as coffee plantations (Coffea arabica Lineu) with 5 years old $(9.7 \%$ 
of the area) and 1 year old (51.8\%), 5 year-old eucalyptus plantation (15.4\%) and native vegetation of secondary forest (14.7\%) and cerrado grasses (8.4\%) (Figure 1).

The study area is occupied by typic Dystrophic Haplic Cambisols (95\% of the area) followed by typic Dystrophic Regolithic Neosols (5\%), classified using the Brazilian Soil Classification System (Embrapa, 2013), both with gravels, developed from metapelitic rocks. Soil samples were collected at three depths: 0 to $10 \mathrm{~cm}, 10$ to $20 \mathrm{~cm}$ and 20 to $40 \mathrm{~cm}$, at 40 places randomly distributed in the area, making up a total of 120 samples (Figure 1).

\section{Laboratory analyses}

Soil samples were air dried, passed through a $2 \mathrm{~mm}$ sieve and analyzed in the laboratory where the following soil properties were determined: soil $\mathrm{pH}$ in water, exchangeable contents of $\mathrm{Ca}^{2+}, \mathrm{Mg}^{2+}$ and $\mathrm{Al}^{3+}$ (Mclean et al., 1958), available K extracted with Mehlich-1, soil organic matter (OM) (Walkley; Black, 1934), remaining P (P-rem) (Alvarez; Fonseca, 1990), potential (T) and effective ( $\mathrm{t}$ ) cation exchange capacity (CEC), and base saturation (V).

The samples were also analyzed in the laboratory with the pXRF of Bruker model S1 Titan LE. This equipment contains $50 \mathrm{kV}$ and $100 \mu \mathrm{A} \mathrm{X}$-ray tubes. The software used was GeoChem, in the Trace (dual soil) configuration, recommended for soils, for 60 seconds, including two X-ray beams. The 120 samples collected were subjected to analysis in triplicate by $\mathrm{pXRF}$ and the accuracy of the equipment was evaluated through scanning standard reference materials $2710 \mathrm{a}$ and 2711a certified by the National Institute of Standards and Technology (NIST) as well as scanning an equipment standard sample (check sample - CS). From the NIST and CS certified samples, the recovery of the element contents obtained by pXRF ( $\%$ of recovery $=100 \mathrm{x}$ Obtained content $/$ Total certified content) were calculated. The recovery percentages of the samples are presented in Table 1 only for the elements that were identified in all the samples of this work.

\section{Analysis of data and modeling}

The results of the laboratory analyses were submitted to descriptive statistics, in the three soil depths evaluated, to obtain the average, maximum and minimum values, standard deviation and coefficient of variation (CV). From the data of the pXRF, models were adjusted to predict the following soil properties: exchangeable $\mathrm{Ca}^{2+}$, $\mathrm{Mg}^{2+}, \mathrm{K}^{+}, \mathrm{Al}^{3+}, \mathrm{P}-\mathrm{rem}, \mathrm{pH}$, potential CEC (T), effective $\mathrm{CEC}(\mathrm{t})$, soil organic matter $(\mathrm{OM})$ and base saturation $(\mathrm{V})$.

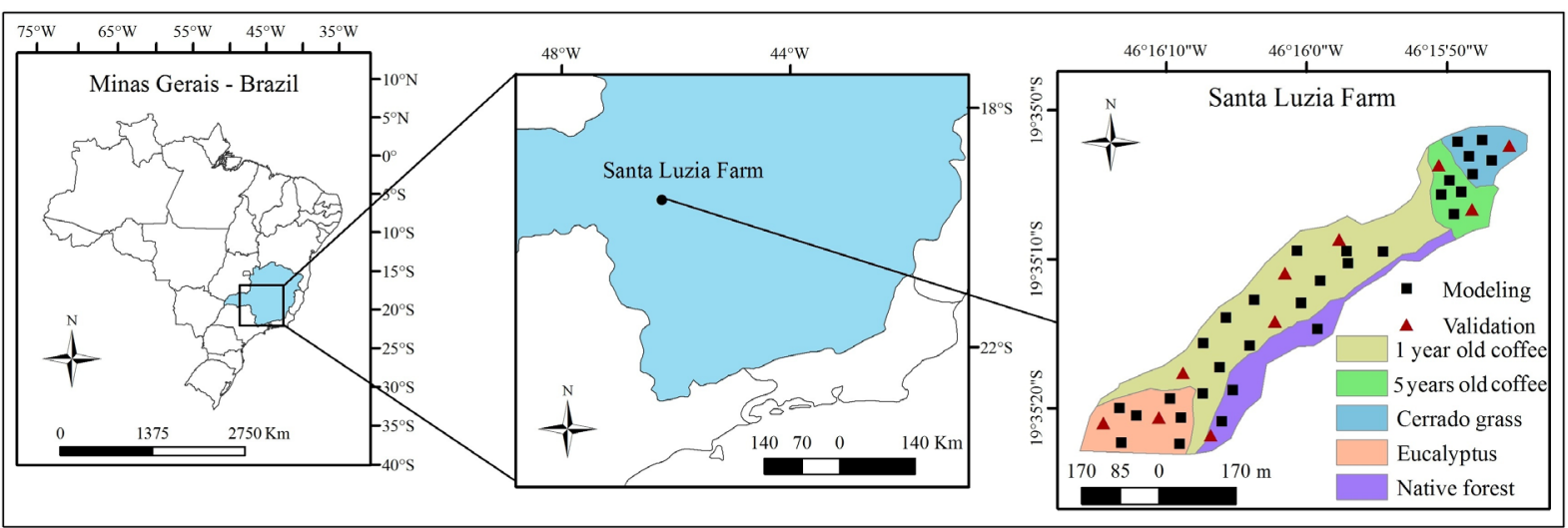

Figure 1: Study area location, land uses and sampling points for modeling and validation.

Table 1: Percentage of recovery of element contents by portable X-ray fluorescence spectrometer (pXRF) of National Institute of Standards and Technology (NIST) and pXRF equipment (CS) certified samples.

\begin{tabular}{cccccccccccccc}
\hline Sample $^{1}$ & $\mathrm{Al}$ & $\mathrm{Si}$ & $\mathrm{P}$ & $\mathrm{K}$ & $\mathrm{Ca}$ & $\mathrm{Ti}$ & $\mathrm{Cr}$ & $\mathrm{Mn}$ & $\mathrm{Fe}$ & $\mathrm{Ni}$ & $\mathrm{Cu}$ & $\mathrm{Zn}$ & $\mathrm{Sr}$ \\
\hline 2710a & 80.2 & 58.7 & 399.8 & 56.1 & 36.0 & 78.4 & - & 71.6 & 76.0 & - & - & - & 97.8 \\
2711a & 67.0 & 49.8 & 574.2 & 44.6 & 42.1 & 70.8 & 118.6 & 63.1 & 68.6 & 98.1 & 75.2 & 82.7 & 92.6 \\
CS & 90.2 & 89.8 & - & 84.2 & - & - & - & 82.5 & 86.8 & 99.4 & 94.4 & - & - \\
\hline
\end{tabular}

${ }^{1}$ 2710a e 2711 a - NIST certified samples; CS - equipment certified sample. 
Soil samples were randomly separated into modeling and validation data sets, respectively, consisting of $75 \%$ and $25 \%$ of the total data. Also, the samples were subdivided and modeled in two ways: i) specific models, according to the three depths of sampling, with $\mathrm{n}=40$ for each depth, with 30 samples for modeling and 10 for validation; and ii) general model, including all samples $(\mathrm{n}=120,90$ for modeling and 30 for validation).

In order to adjust the models for predicting soil property results from the pXRF data, two methods were tested: stepwise multiple linear regression (SMLR) and random forest algorithm (RF). The SMLR was generated through SigmaPlot software, backward method, in which the least important variables for model adjustment are removed, with $95 \%$ probability.

The random forest analysis was performed in $\mathrm{R}$ software, randomForest package (Liaw and Wiener, 2015), with the following parameters established: number of trees of the model (ntrees) $=1000$, number of variables in each node (nodesize $)=5$, and number of variables used in each tree $(\mathrm{mtry})=$ one third of the total number of samples, as suggested by Liaw and Wiener (2002) for regression random forests.

The random forest adjustment results in the mean square of the residuals $\left(\mathrm{MSE}_{\mathrm{oob}}\right)$, the percentage of the variance explained by the model and the importance of all the variables of the model in the prediction of the data, by the out-of-bag method. $\mathrm{MSE}_{\text {oob }}$ is calculated when, for each iteration, only a few predictor variables are used to generate a tree. The $\mathrm{MSE}_{\text {oob }}$ is calculated through Equation 1. The importance of the variables, also obtained by the algorithm, is a result of the average of the reduction of the accuracy in the prediction as one variable is left out of the model while the other variables are included. Thus, if a variable is removed, the more the prediction error increases, which means, the accuracy of the prediction decreases, the more important that variable is for the model adjustment (Breiman, 2001; Liaw; Wiener, 2002).

$\operatorname{MSEOob}=\frac{1}{n} \sum_{1}^{n}\left[y_{i}-y_{i}^{O O B}\right]^{2}$

in which $y_{i}$ is the real (observed) value, $y_{i}^{\text {Оов }}$ is the mean of the predictions of OOB for the $i^{\text {th }}$ observation, $n$ is the number of trees.

\section{Accuracy of the models}

The validation of the general and specific (per depth) models generated by SMLR and random forest was performed using the independent subset of data (not used in the modeling), consisting of $25 \%$ of the total data, to determine if the predictions by the models are valid for other observed data. For this, the estimated values for each sample of the independent subset were determined and the accuracy of the models was evaluated through the following statistical indices: coefficient of determination $\left(\mathrm{R}^{2}\right)$, adjusted $\mathrm{R}^{2}\left(\mathrm{R}_{\text {adj }}^{2}\right)$ in relation to observed and estimated data, root mean square error (RMSE), and mean error (ME), according to Equations 2 and 3:

$$
\begin{aligned}
& R M S E=\sqrt{\frac{1}{n} \sum_{i=1}^{n}(e i-m i)^{2}} \\
& M E=\frac{1}{n} \sum_{i=1}^{n}(e i-m i)
\end{aligned}
$$

where n: number of observations, ei: values estimated by the model, and mi: values observed through laboratory analysis.

The efficiency of the modeling methods (SMLR and random forest) was carried out in addition to the determination of the analytical results capable of being predicted with greater accuracy from the generated models. In this sense, the models that obtained the highest values of $\mathrm{R}^{2}$ and $\mathrm{R}_{\text {adj }}$ and the smallest RMSE and ME comparing observed with estimated data were considered the best for prediction of the results of laboratory analysis from the pXRF data.

\section{Spatial prediction of soil properties from pXRF data}

From the definition of the best method for modeling, the laboratory results that presented high accuracy of predictions were spatialized for the entire study area. This procedure aimed to evaluate the possibility of using pXRF data as a basis for mapping soil properties (Duda et al., 2017; Silva et al., 2016b), providing easily obtainable variables, at low cost, rapidly and with no generation of chemical residues.

First in this procedure it was necessary to spatialize the variables obtained by pXRF for the entire study area, since the soil properties prediction models are based on pXRF data, which, in turn, only refer to the sites at where samples were collected. In order to do so, the inverse distance weighting (IDW) method was employed in the spatialization of the pXRF variables, allowing their subsequent use for mapping. The values inferred at non-sampled areas by IDW are estimated using linear combination of values at the sampled places, weighted by an inverse function of the distance from the point of interest to the sample points. The weights $\left(\lambda_{i}\right)$ are expressed in Equation 4: 


$$
\lambda_{i}=\frac{\frac{1}{d_{i}^{p}}}{\sum_{i=1}^{n} \frac{1}{d_{i}^{p}}}
$$

where $d_{i}$ is the distance between two points, $p$ is a power parameter, and $n$ represents the number of sampled points used for the estimation.

The predicted maps of the soil properties were also validated with $25 \%$ of the samples (not used for the modeling) through the $\mathrm{R}^{2}, \mathrm{R}_{\text {adj }}^{2}$, RMSE, ME and 1: 1 graphs (observed vs. estimated data).

\section{RESULTS AND DISCUSSION}

\section{Descriptive statistics}

The analytical data of the samples used for modeling and validation are presented in Table 2. There is great variability of values of all evaluated soil properties, as demonstrated by the high coefficients of variation, in both modeling and validation data sets. This occurred, as expected, due to the different land uses of the area and soil management practices, ranging from native vegetation, where $\mathrm{pH}$ and nutrient contents are lower since no anthropic influence occurs, to cultivated areas, where these values are higher because of liming and fertilizers application. This variability of data can contribute to the generation of more reliable models with possible use for soils with different conditions, since the used values contemplate a wide range of values of the analyzed properties, such as P-rem varying from 10.8 to $47.1 \mathrm{mg} \mathrm{dm}^{-3}$, and $\mathrm{pH}$, from 4.4 to 7.7 .

As a general trend, the exchangeable/available nutrient contents as well as $\mathrm{pH}, \mathrm{OM}, \mathrm{T}, \mathrm{t}$, and $\mathrm{V}$ decreased from the surface to the subsurface, contrary to the exchangeable Al that increases in depth. These facts are in agreement with the fertilizer applications and liming practices, which are carried out on the more superficial soil layers.Furthermore, although liming decreases the content of exchangeable Al, this product moves very little in depth in the soil, thus, its corrective effect is more concentrated on the layer in which it is incorporated (Alvarez; Ribeiro, 1999).

Table 2: Descriptive statistics of soil properties in modeling and validation data sets.

\begin{tabular}{|c|c|c|c|c|c|c|c|c|c|c|c|}
\hline \multirow{2}{*}{$\begin{array}{c}\text { Soil } \\
\text { Property }\end{array}$} & \multirow{2}{*}{$\begin{array}{l}\text { Depth } \\
\text { (cm) }\end{array}$} & \multicolumn{5}{|c|}{ Modeling ${ }^{1}$} & \multicolumn{5}{|c|}{ Validation $^{2}$} \\
\hline & & Min & Max & Mean & STD & CV (\%) & Min & Max & Mean & STD & CV (\%) \\
\hline \multirow{5}{*}{$\mathrm{pH}$} & 0 to 10 & 4.5 & 7.7 & 5.9 & 1.2 & 20.3 & 4.7 & 7.5 & 5.8 & 1.1 & 19.0 \\
\hline & 10 to 20 & 4.4 & 7.7 & 5.6 & 0.9 & 16.1 & 4.2 & 7.5 & 5.4 & 0.9 & 16.7 \\
\hline & 20 to 40 & 4.6 & 7.2 & 5.2 & 0.5 & 9.6 & 3.9 & 7.1 & 5.2 & 0.8 & 15.4 \\
\hline & General & 4.4 & 7.7 & 5.6 & 0.9 & 16.1 & 3.9 & 7.5 & 5.4 & 0.9 & 16.7 \\
\hline & 0 to 10 & 36.9 & 381.6 & 134.7 & 82.3 & 61.1 & 39.1 & 161.7 & 105.9 & 46.1 & 43.5 \\
\hline \multirow{4}{*}{$\begin{array}{c}\mathrm{K} \\
\left(\mathrm{mg} \mathrm{dm} \mathrm{m}^{-3}\right)\end{array}$} & 10 to 20 & 32.5 & 535.3 & 137.6 & 130.1 & 94.5 & 28.1 & 276.2 & 100.7 & 74.5 & 74.0 \\
\hline & 20 to 40 & 21.5 & 579.6 & 115 & 131.6 & 114.4 & 17.1 & 289.6 & 88.7 & 86.9 & 98.0 \\
\hline & General & 21.5 & 579.6 & 129.1 & 116 & 89.9 & 17.1 & 289.6 & 98.4 & 69.1 & 70.2 \\
\hline & 0 to 10 & 0.1 & 7.9 & 2.6 & 2.5 & 96.2 & 0.1 & 7.3 & 2.4 & 2.5 & 104.2 \\
\hline \multirow{4}{*}{$\begin{array}{c}\mathrm{Ca} \\
\left(\mathrm{cmol}_{\mathrm{c}} \mathrm{dm}^{-3}\right)\end{array}$} & 10 to 20 & 0.1 & 5.7 & 1.6 & 1.7 & 106.3 & 0.1 & 5.1 & 1.1 & 1.6 & 145.5 \\
\hline & 20 to 40 & 0.1 & 5.0 & 0.7 & 1.1 & 157.1 & 0.1 & 3.4 & 0.6 & 1.0 & 166.7 \\
\hline & General & 0.1 & 7.9 & 1.6 & 2 & 125.0 & 0.1 & 7.3 & 1.4 & 1.9 & 135.7 \\
\hline & 0 to 10 & 0.1 & 3.1 & 0.7 & 0.8 & 114.3 & 0.1 & 1.9 & 0.6 & 0.6 & 100.0 \\
\hline \multirow{3}{*}{$\begin{array}{c}\mathrm{Mg} \\
\left(\mathrm{cmol}_{\mathrm{c}} \mathrm{dm}^{-3}\right)\end{array}$} & 10 to 20 & 0.1 & 1.7 & 0.6 & 0.6 & 100.0 & 0.1 & 2.3 & 0.5 & 0.7 & 140.0 \\
\hline & 20 to 40 & 0.1 & 1.0 & 0.2 & 0.2 & 100.0 & 0.1 & 1.3 & 0.3 & 0.4 & 133.3 \\
\hline & General & 0.1 & 3.1 & 0.5 & 0.6 & 120.0 & 0.1 & 2.3 & 0.4 & 0.6 & 150.0 \\
\hline
\end{tabular}


Table 2: Continuation...

\begin{tabular}{|c|c|c|c|c|c|c|c|c|c|c|c|}
\hline \multirow{2}{*}{$\begin{array}{c}\text { Soil } \\
\text { Property }{ }^{1}\end{array}$} & \multirow{2}{*}{$\begin{array}{l}\text { Depth } \\
\text { (cm) }\end{array}$} & \multicolumn{5}{|c|}{ Modeling ${ }^{1}$} & \multicolumn{5}{|c|}{ Validation ${ }^{2}$} \\
\hline & & Min & Max & Mean & STD & CV (\%) & Min & Max & Mean & STD & CV (\%) \\
\hline \multirow{4}{*}{$\begin{array}{l}\text { P-Rem } \\
\left(\mathrm{mg} \mathrm{dm}^{-3}\right)\end{array}$} & 0 to 10 & 15.3 & 47.1 & 31.2 & 8.8 & 28.2 & 22.5 & 46.9 & 33.3 & 8.6 & 25.8 \\
\hline & 10 to 20 & 13.2 & 39.7 & 27 & 7.5 & 27.8 & 16.2 & 44.4 & 28.4 & 8.3 & 29.2 \\
\hline & 20 to 40 & 10.8 & 34.9 & 25.0 & 6.0 & 24.0 & 16.1 & 39.2 & 26.4 & 6.3 & 23.9 \\
\hline & General & 10.8 & 47.1 & 27.7 & 7.9 & 28.5 & 16.1 & 46.9 & 29.4 & 8.1 & 27.6 \\
\hline \multirow{5}{*}{$\begin{array}{c}\mathrm{Al} \\
\left(\mathrm{cmol}_{\mathrm{c}} \mathrm{dm}^{-3}\right)\end{array}$} & 0 to 10 & 0.0 & 3.7 & 1.1 & 1.3 & 118.2 & 0.0 & 2.6 & 1.0 & 1.1 & 110.0 \\
\hline & 10 to 20 & 0.0 & 4.0 & 1.3 & 1.3 & 100.0 & 0.0 & 3.4 & 1.4 & 1.2 & 85.7 \\
\hline & 20 to 40 & 0.0 & 3.4 & 1.5 & 0.9 & 60.0 & 0.0 & 2.6 & 1.5 & 0.8 & 53.3 \\
\hline & General & 0.0 & 4.0 & 1.3 & 1.2 & 92.3 & 0.0 & 3.4 & 1.3 & 1.0 & 76.9 \\
\hline & 0 to 10 & 1.9 & 11.4 & 4.8 & 2.5 & 52.1 & 2.5 & 9.2 & 4.2 & 2.3 & 54.8 \\
\hline \multirow{3}{*}{$\left(\mathrm{cmol}_{\mathrm{c}} \mathrm{dm}^{-3}\right)$} & 10 to 20 & 1.7 & 8.2 & 3.8 & 1.6 & 42.1 & 1.9 & 7.8 & 3.3 & 1.7 & 51.5 \\
\hline & 20 to 40 & 1.5 & 7.4 & 2.8 & 1.1 & 39.3 & 1.7 & 5.5 & 2.5 & 1.1 & 44.0 \\
\hline & General & 1.5 & 11.4 & 3.8 & 2 & 52.6 & 1.7 & 9.2 & 3.3 & 1.8 & 54.5 \\
\hline \multirow{4}{*}{$\left(\mathrm{cmol}_{\mathrm{c}}^{\mathrm{T}} \mathrm{dm}^{-3}\right)$} & 0 to 10 & 5.5 & 14.4 & 8.5 & 2.4 & 28.2 & 4.9 & 10.3 & 7.4 & 1.8 & 24.3 \\
\hline & 10 to 20 & 4.8 & 15.9 & 7.8 & 2.6 & 33.3 & 4.9 & 8.8 & 6.7 & 1.3 & 19.4 \\
\hline & 20 to 40 & 3.9 & 13.7 & 6.5 & 2.4 & 36.9 & 4.3 & 6.9 & 5.6 & 0.9 & 16.1 \\
\hline & General & 3.9 & 15.9 & 7.6 & 2.6 & 34.2 & 4.3 & 10.3 & 6.6 & 1.5 & 22.7 \\
\hline \multirow{4}{*}{$\begin{array}{l}\mathrm{V} \\
(\%)\end{array}$} & 0 to 10 & 2.7 & 93.1 & 44.5 & 38.3 & 86.1 & 3.7 & 89.3 & 43.4 & 35 & 80.6 \\
\hline & 10 to 20 & 2.3 & 87 & 35.3 & 32.9 & 93.2 & 3.7 & 88.5 & 27.2 & 29 & 106.6 \\
\hline & 20 to 40 & 3.1 & 82.4 & 20.2 & 20.2 & 100.0 & 4.0 & 79.2 & 17.7 & 22.8 & 128.8 \\
\hline & General & 2.3 & 93.1 & 33.4 & 32.6 & 97.6 & 3.7 & 89.3 & 29.4 & 30.3 & 103.1 \\
\hline \multirow{4}{*}{$\begin{array}{c}\mathrm{OM} \\
\left(\operatorname{dag~kg}^{-1}\right)\end{array}$} & 0 to 10 & 2.3 & 9.2 & 3.7 & 1.4 & 37.8 & 1.7 & 6.7 & 3.4 & 1.5 & 44.1 \\
\hline & 10 to 20 & 1.6 & 4.3 & 2.7 & 0.8 & 29.6 & 1.7 & 3.6 & 2.4 & 0.7 & 29.2 \\
\hline & 20 to 40 & 1.1 & 3.8 & 1.9 & 0.6 & 31.6 & 1.1 & 2.3 & 1.7 & 0.4 & 23.5 \\
\hline & General & 1.1 & 9.2 & 2.8 & 1.2 & 42.9 & 1.1 & 6.7 & 2.5 & 1.2 & 48.0 \\
\hline
\end{tabular}

130 samples for 0 to $10 \mathrm{~cm}, 10$ to $20 \mathrm{~cm}$ and 20 to $40 \mathrm{~cm}$, and 90 samples for General; 210 samples for 0 to $10 \mathrm{~cm}$, 10 to $20 \mathrm{~cm}$ and 20 to $40 \mathrm{~cm}$, and 30 samples for General; Min: minimum value; Max: maximum value; STD: standard deviation; CV: coefficient of variation; P-Rem: Remaining phosphorus; t: effective cation exchange capacity; T: potential cation exchange capacity; $\mathrm{V}$ : base saturation; OM: organic matter.

The $\mathrm{pXRF}$ determined 16 elements for all analyzed samples, being them $\mathrm{Al}_{2} \mathrm{O}_{3}, \mathrm{Fe}, \mathrm{SiO}_{2}, \mathrm{CaO}, \mathrm{P}_{2} \mathrm{O}_{5}, \mathrm{~K}_{2} \mathrm{O}$, Cl, $\mathrm{Ti}, \mathrm{V}, \mathrm{Cr}, \mathrm{Mn}, \mathrm{Ni}, \mathrm{Cu}, \mathrm{Zn}, \mathrm{Zr}$ e Sr. Table 3 presents the descriptive statistics for the pXRF data.

\section{Modeling soil properties through stepwise multiple linear regression}

Analyzing Figure 2, which shows the $\mathrm{R}^{2}$ values from the SMLR models, it is noticed that high values were found with at least one model obtaining $\mathrm{R}^{2}$ greater than 0.8 for all of the soil properties, except for T. Among the three depths, 0 to 10 and 20 to 40 presented, in general, higher values than 10 to 20 . The latter only presented better adjustment for OM and $t$. These values indicate the potentiality of using $\mathrm{pXRF}$ to provide variables for adjusting prediction equations of soil properties in tropical regions. Works such as Sharma et al. (2015), who used pXRF data to perform CTC prediction in soils of the United States, obtaining adequate results using SMLR, corroborate the appropriate soil property predictions from $\mathrm{pXRF}$ data. 


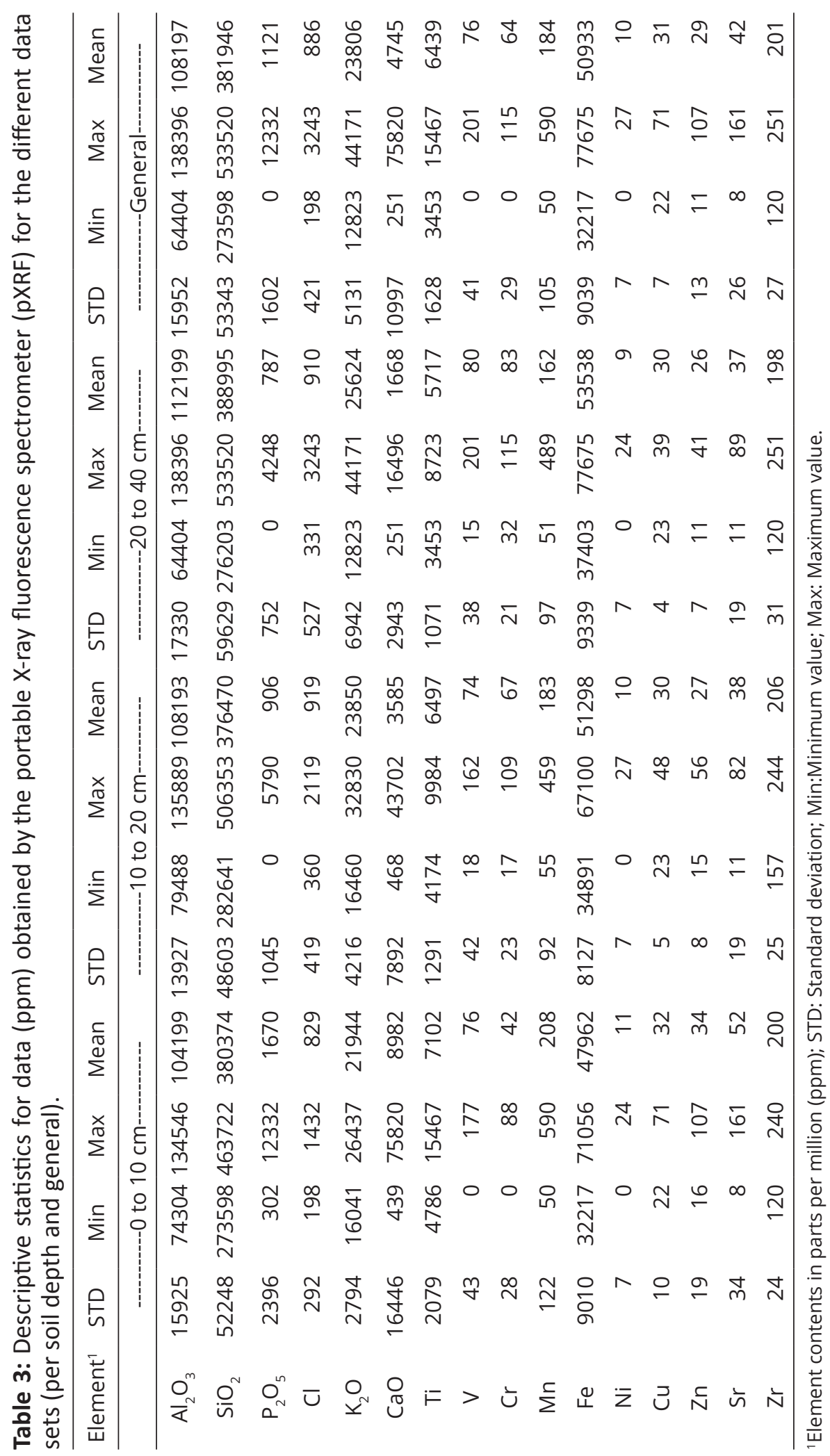




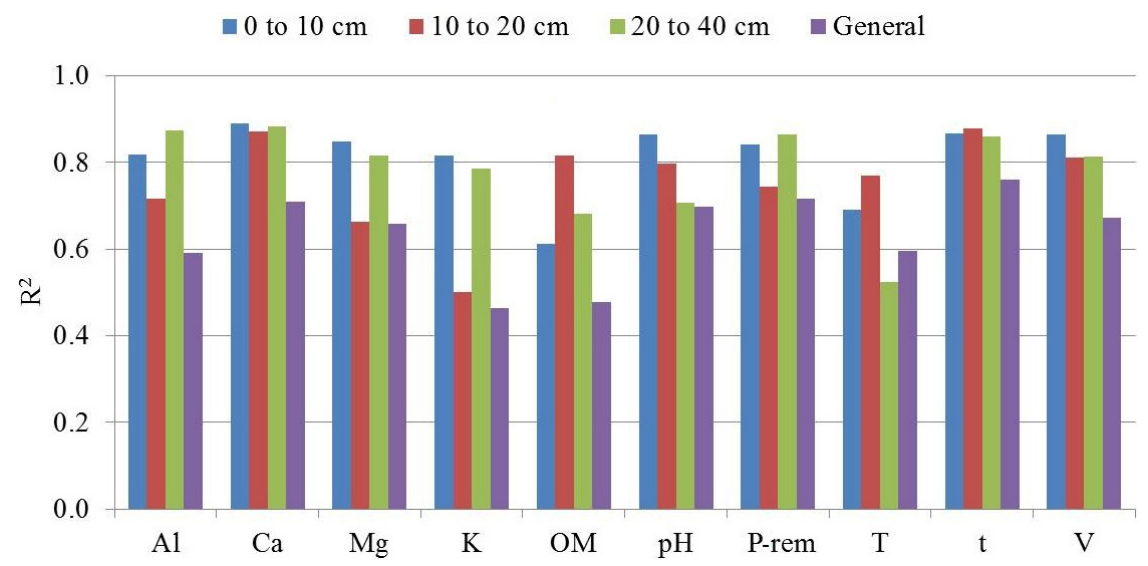

Figure 2: Coefficient of determination $\left(R^{2}\right)$ of the equations to modeling soil properties through stepwise multiple linear regression. $\mathrm{Al}, \mathrm{Ca}, \mathrm{Mg}$ and $\mathrm{K}$ represent the exchangeable/available contents of these elements; $\mathrm{OM}$ - organic matter; P-rem - remaining P; T - potential cation exchange capacity; t - effective cation exchange capacity; V - base saturation.

The general equation presented lower $\mathrm{R}^{2}$ values in most cases, which may be due to the greater heterogeneity of the samples used in this modeling. In contrast, these results demonstrate that adjusting equations according to the depth of sampling tends to provide better models using SMLR. Souza et al. (2016) used SMLR for bulk density prediction, comparing models created only for A horizon, only for B horizon and a general one, encompassing the two horizons, and also obtained better adjustments for the equations for horizons separately in relation to the general model.

Table 4 shows the equations with $\mathrm{R}^{2}$ values greater than or equal to 0.80 generated for 0 to $10 \mathrm{~cm}, 10$ to 20 $\mathrm{cm}, 20$ to $40 \mathrm{~cm}$. The general models did not reach $\mathrm{R}^{2}$ of 0.80 . It is noticed that, in the 17 equations presented, the $\mathrm{CaO}$ content was the one that appeared more often $(15$ equations), followed by $\mathrm{SiO}_{2}$ (12 equations) and $\mathrm{Fe}$ (11 equations). Also, for 0 to $10 \mathrm{~cm}, 8$ equations presented $\mathrm{R}^{2}$ of at least 0.80 , against 4 for 10 to $20 \mathrm{~cm}$ and 5 for 20 to $40 \mathrm{~cm}$. Thus, these equations indicate that exchangeable $\mathrm{Ca}, \mathrm{Mg}, \mathrm{K}, \mathrm{Al}$ as well as $\mathrm{P}$-rem, $\mathrm{pH}, \mathrm{t}, \mathrm{V}(\%)$ and $\mathrm{OM}$ could be adequately modeled by SMLR using $\mathrm{pXRF}$ data.

\section{Modeling soil properties through random forest}

Table 5 shows the results of random forest modeling: $\mathrm{MSE}_{\text {oob }}$ and the percentage of variance explained for each model (general and specific). With the exception of $\mathrm{Mg}$, it is observed that the percentage of the variance explained by the models for the analyzed soil properties decreased in depth, being greater, therefore, for the 0 to $10 \mathrm{~cm}$ depth and smaller for the 20 to $40 \mathrm{~cm}$ depth. However, the general model was the one that presented the lowest $\mathrm{MSE}_{\text {oob }}$ and the highest percentages of the explained variance. This may be due to the greater amount of data used for this model ( $\mathrm{n}=$ 90) relative to the models for only one depth $(n=30)$. This result is contrary to that found with SMLR modeling, in which the general models were mostly worse than the specific ones (by depth). Carvalho Junior et al. (2016) compared SMLR models generated with different sets of variables and number of samples to estimate the bulk density and noticed that $\mathrm{R}^{2}$ values were lower for the models with greater amount of samples. In the same work, they noticed that the models generated by random forest with greater amount of data presented better adjustments than those with smaller amount of data, in agreement with the findings of this work.

Table 5 indicates that the soil properties most explained by the general and specific random forest models were base saturation, exchangeable $\mathrm{Ca}$ and $\mathrm{Al}$, and $\mathrm{pH}$, whereas $\mathrm{OM}$ and $\mathrm{T}$ were the least explained. $\mathrm{K}$ was the variable with the highest $\mathrm{MSE}_{\text {oob }}$, indicating larger prediction errors (to be confirmed by the validation of the models).

\section{Validation of models generated with stepwise multiple linear regression and random forest}

The $\mathrm{R}^{2}$ values resulted from the comparison between the observed and estimated values generated by SMLR and random forest for the validation of samples are presented in Tables 6 and 7. It is noted that the highest $R^{2}$ values were obtained in predictions with random forest rather than with SMLR for the soil properties, except for K. Available K was also the predicted soil property that presented the highest $\mathrm{MSE}_{\text {oob }}$ values in the modeling phase (Table 5). Differences were verified between the $\mathrm{R}^{2}$ values of the validation of the analyzed properties prediction with random forest models 
and SMLR, especially exchangeable $\mathrm{Ca}$ and $\mathrm{Al}, \mathrm{pH}$ and $\mathrm{t}$, being them better predicted with random forest. This suggests that random forest presents greater potential for estimating analytical results, reflecting soil properties, from $\mathrm{pXRF}$ data.

RMSE, ME and $\mathrm{R}_{\text {adj }}^{2}$, presented in Tables 6 and 7, corroborate the best predictions with random forest in relation to the SMLR. Souza et al. (2016) compared model adjustments for predicting bulk density using SMLR and random forest, also obtaining better results with random forest, in consonance with this work.
In the validation of the models obtained with SMLR, only pH of the 20 to $40 \mathrm{~cm}$ depth model and of the general model, exchangeable $\mathrm{Al}$ in general model, and $\mathrm{t}$ and $\mathrm{OM}$ by the 20 to $40 \mathrm{~cm}$ depth model presented RMSE values lower than 1.0, while in the validation by random forest, $\mathrm{Ca}, \mathrm{pH}, \mathrm{Al}, \mathrm{Mg}$, $\mathrm{t}$ and $\mathrm{OM}$ showed values lower than that at all depths and in the general model (Tables 6 and 7). The absolute values of ME were also mostly smaller for the validation of the random forest models in relation to the SMLR models.

Table 4: Stepwise multiple linear regression equations with $\mathrm{R}^{2} \geq 0.80$, in different depths to predict exchangeable $\mathrm{Ca}\left(\mathrm{cmol}_{c} \mathrm{dm}^{-3}\right)$, exchangeable $\mathrm{Mg}\left(\mathrm{cmol}_{\mathrm{c}} \mathrm{dm}^{-3}\right)$, available $\mathrm{K}\left(\mathrm{mg} \mathrm{dm}{ }^{-3}\right)$, exchangeable Al $\left(\mathrm{cmol}_{c} \mathrm{dm}^{-3}\right)$, $\mathrm{pH}$, effective cation exchange capacity $(\mathrm{t})\left(\mathrm{cmol}_{c} \mathrm{dm}^{-3}\right)$, base saturation (V) (\%), remaining P (P-rem) (mg dm$\left.{ }^{-3}\right)$ and organic matter content (OM) (\%) from pXRF data (ppm).

\begin{tabular}{|c|c|}
\hline Equation & $\mathrm{R}^{2}$ \\
\hline \multicolumn{2}{|l|}{ 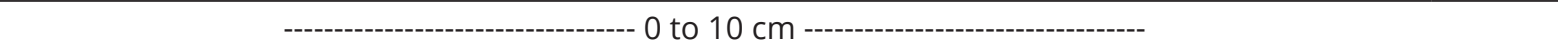 } \\
\hline $\begin{array}{c}\mathrm{Ca}=13.211+0.0000481 \mathrm{Al}_{2} \mathrm{O}_{3}-0.0000213 \mathrm{SiO}_{2}-0.000950 \mathrm{P}_{2} \mathrm{O}_{5}+0.00358 \mathrm{Cl}-0.0436 \mathrm{Cr}-0.000257 \mathrm{Fe} \\
+0.232 \mathrm{Cu}+0.0326 \mathrm{Sr}-0.0192 \mathrm{Zr}\end{array}$ & 0.89 \\
\hline $\mathrm{Mg}=1.903+0.0000984 \mathrm{~K}_{2} \mathrm{O}+0.0000332 \mathrm{CaO}-0.00867 \mathrm{Cr}-0.00176 \mathrm{Mn}-0.0146 \mathrm{Zr}$ & 0.85 \\
\hline $\mathrm{K}=32.668+0.0133 \mathrm{~K}_{2} \mathrm{O}+0.00329 \mathrm{CaO}+0.621 \mathrm{~V}-2.088 \mathrm{Cr}-0.327 \mathrm{Mn}+6.258 \mathrm{Cu}-2.352 \mathrm{Sr}-0.937 \mathrm{Zr}$ & 0.81 \\
\hline $\begin{array}{c}\mathrm{Al}=3.053+0.000835 \mathrm{P}_{2} \mathrm{O}_{5}-0.00163 \mathrm{Cl}-0.0000676 \mathrm{CaO}+0.0103 \mathrm{~V}+0.0299 \mathrm{Cr}+0.00383 \mathrm{Mn}- \\
0.131 \mathrm{Cu}\end{array}$ & 0.82 \\
\hline $\begin{array}{c}\mathrm{pH}=6.442-0.00000519 \mathrm{SiO}_{2}-0.000615 \mathrm{P}_{2} \mathrm{O}_{5}+0.00102 \mathrm{Cl}+0.000100 \mathrm{~K}_{2} \mathrm{O}+0.0000816 \mathrm{CaO}- \\
0.0209 \mathrm{Cr}-0.0000533 \mathrm{Fe}+0.0677 \mathrm{Cu}\end{array}$ & 0.86 \\
\hline $\mathrm{t}=6.281+0.000352 \mathrm{~K}_{2} \mathrm{O}-0.0373 \mathrm{Cr}-0.00586 \mathrm{Mn}+0.0706 \mathrm{Zn}-0.0442 \mathrm{Zr}$ & 0.87 \\
\hline 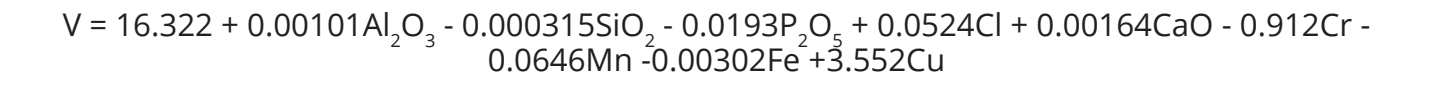 & 0.89 \\
\hline 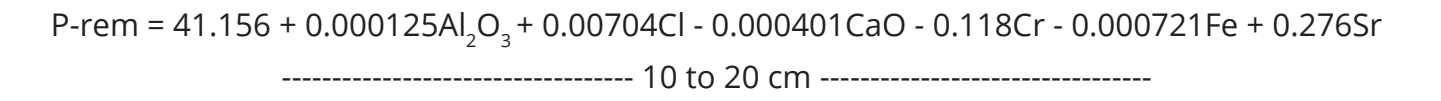 & 0.84 \\
\hline $\begin{array}{c}\mathrm{Ca}=4.449+0.0000756 \mathrm{Al}_{2} \mathrm{O}_{3}-0.0000113 \mathrm{SiO}_{2}+0.000217 \mathrm{CaO}+0.00131 \mathrm{Ti}+0.0143 \mathrm{~V}-0.000323 \mathrm{Fe}- \\
0.0561 \mathrm{Ni}+0.269 \mathrm{Cu}-0.296 \mathrm{Zn}\end{array}$ & 0.87 \\
\hline $\begin{array}{c}\mathrm{t}=12.538+0.0000671 \mathrm{Al}_{2} \mathrm{O}_{3}-0.0000223 \mathrm{SiO}_{2}+0.000203 \mathrm{CaO}+0.000725 \mathrm{Ti}+0.0189 \mathrm{~V}+0.00607 \mathrm{Mn}- \\
0.000294 \mathrm{Fe}+0.190 \mathrm{Cu}-0.226 \mathrm{Zn}\end{array}$ & 0.87 \\
\hline $\begin{aligned} \mathrm{V}=113.847+0.00145 \mathrm{Al}_{2} \mathrm{O}_{3}-0.000221 \mathrm{SiO}_{2} & +0.00418 \mathrm{CaO}+0.0304 \mathrm{Ti}+0.309 \mathrm{~V}-0.00675 \mathrm{Fe}-1.449 \mathrm{Ni} \\
& +4.983 \mathrm{Cu}-6.450 \mathrm{Zn}\end{aligned}$ & 0.81 \\
\hline $\begin{array}{c}\mathrm{OM}=4.057+0.0000406 \mathrm{Al}_{2} \mathrm{O}_{3}-0.0000121 \mathrm{SiO}_{2}-0.000512 \mathrm{Cl}+0.000119 \mathrm{CaO}+0.0000697 \mathrm{Fe}- \\
0.0432 \mathrm{Ni}-0.0746 \mathrm{Cu}-0.0543 \mathrm{Sr}\end{array}$ & 0.82 \\
\hline -------------------------------- 20 to 40 cm -------------------------------- & \\
\hline $\mathrm{Ca}=-2.866+0.00000409 \mathrm{SiO}_{2}+0.0000237 \mathrm{~K}_{2} \mathrm{O}+0.000318 \mathrm{CaO}+0.000150 \mathrm{Ti}$ & 0.88 \\
\hline $\begin{array}{c}\mathrm{Al}=10.433-0.0000173 \mathrm{SiO}_{2}+0.000722 \mathrm{P}_{2} \mathrm{O}_{5}-0.000112 \mathrm{~K}_{2} \mathrm{O}-0.000290 \mathrm{CaO}-0.000400 \mathrm{Ti}+0.0202 \mathrm{Cr} \\
+0.00502 \mathrm{Mn}-0.0000890 \mathrm{Fe}+0.0661 \mathrm{Zn} 0.0173 \mathrm{Zr}\end{array}$ & 0.87 \\
\hline $\mathrm{t}=4.037-0.00000469 \mathrm{SiO}_{2}-0.000506 \mathrm{Cl}+0.000334 \mathrm{CaO}+0.00278 \mathrm{Mn}$ & 0.86 \\
\hline$V=-71.659+0.000172 \mathrm{SiO}_{2}-0.00931 \mathrm{Cl}+0.00134 \mathrm{~K}_{2} \mathrm{O}+0.00404 \mathrm{CaO}+0.00503 \mathrm{Ti}+0.346 \mathrm{Sr}-0.247 \mathrm{Zr}$ & 0.81 \\
\hline $\begin{array}{c}\text { P-rem }=-26.468+0.000121 \mathrm{SiO}_{2}-0.00390 \mathrm{P}_{2} \mathrm{O}_{5}+0.000751 \mathrm{~K} \mathrm{O}_{2}+0.00150 \mathrm{CaO}-0.193 \mathrm{Cr}-0.0126 \mathrm{Mn} \\
+0.000490 \mathrm{Fe}-0.612 \mathrm{Zn}+0.141 \mathrm{Sr}^{-0.0576 \mathrm{Zr}}\end{array}$ & 0.86 \\
\hline
\end{tabular}


Table 5: Mean error of prediction by the out-of-bag method (MSE ${ }_{\text {oob }}$ ) and percentage of the explained variance of the models originated using the random forest algorithm.

\begin{tabular}{|c|c|c|c|c|c|c|c|c|}
\hline $\begin{array}{c}\text { Soil } \\
\text { Property }\end{array}$ & $\mathrm{MSE}_{\mathrm{oob}}$ & Var exp $(\%)^{2}$ & $\mathrm{MSE}_{\mathrm{oob}}$ & Var exp (\%) & $\mathrm{MSE}_{\mathrm{oob}}$ & Var exp (\%) & $\mathrm{MSE}_{\mathrm{oob}}$ & $\begin{array}{c}\text { Var exp } \\
(\%)\end{array}$ \\
\hline & \multicolumn{2}{|c|}{---------0 to 10-------- } & \multicolumn{2}{|c|}{--------10 to 20-------- } & \multicolumn{2}{|c|}{-------20 to 40------- } & \multicolumn{2}{|c|}{----General----- } \\
\hline $\mathrm{Ca}$ & 1.46 & 76.42 & 0.64 & 77.22 & 0.69 & 75.63 & 0.42 & 89.42 \\
\hline P-rem & 25.35 & 65.91 & 24.50 & 55.31 & 24.36 & 55.57 & 15.98 & 73.82 \\
\hline K & 4148.18 & 36.57 & 12319.80 & 24.73 & 12174.27 & 25.61 & 7933.45 & 40.42 \\
\hline $\mathrm{Al}$ & 0.39 & 76.34 & 0.45 & 71.26 & 0.47 & 70.06 & 0.27 & 80.29 \\
\hline $\mathrm{Mg}$ & 0.30 & 56.55 & 0.11 & 68.02 & 0.12 & 65.05 & 0.13 & 66.24 \\
\hline $\mathrm{pH}$ & 0.41 & 68.30 & 0.24 & 67.26 & 0.25 & 65.86 & 0.15 & 82.90 \\
\hline $\mathrm{OM}$ & 1.57 & 21.12 & 0.56 & 2.39 & 0.54 & 5.54 & 1.21 & 21.38 \\
\hline $\mathrm{T}$ & 5.18 & 4.88 & 6.41 & -1.89 & 6.57 & -4.50 & 4.56 & 29.67 \\
\hline $\mathrm{t}$ & 1.86 & 68.11 & 1.07 & 58.32 & 1.11 & 56.94 & 0.76 & 80.50 \\
\hline V & 253.46 & 82.08 & 232.07 & 77.77 & 212.61 & 79.63 & 100.07 & 90.49 \\
\hline
\end{tabular}

${ }^{1} \mathrm{Ca}, \mathrm{Mg}, \mathrm{Al}, \mathrm{T}$ and $\mathrm{t}$ in $\mathrm{cmol}_{\mathrm{c}} \mathrm{dm}^{-3}$; P-rem and $\mathrm{K}$ in $\mathrm{mg} \mathrm{dm}{ }^{-3}$; OM in dag $\mathrm{kg}^{-1}$; $\mathrm{V}$ in \%; ${ }^{2} \mathrm{Var}$ exp (\%) = percentage of the variance of the models explained.

\section{Importance of variables}

By analyzing the importance of the variables for the explanation of the data with random forest, eight out of the ten soil properties predicted through $\mathrm{pXRF}$ data had $\mathrm{CaO}$ as the most important variable (Table 8, Figure 3 ) and, among these ten soil properties, base saturation, and exchangeable $\mathrm{Al}$ and $\mathrm{Ca}$ had $\mathrm{Cr}$ as the second most important variable. $\mathrm{P}_{2} \mathrm{O}_{5}$ was the most important variable to predict $\mathrm{OM}$, followed by $\mathrm{Zn}$, whereas $\mathrm{SiO}_{2}$ was the most important to predict $\mathrm{T}$, with $\mathrm{P}_{2} \mathrm{O}_{5}$ as the second most important variable. Aldabaa et al. (2015) used pXRF, remote sensing data and visible infrared diffuse reflectance spectroscopy (VisNIR DRS) to predict values of electrical conductivity and verified that, among the $\mathrm{pXRF}$ variables, $\mathrm{Cl}$ and $\mathrm{S}$ were the most important elements for predictions.

The frequency that each $\mathrm{pXRF}$ variable appeared in the first three positions of importance for the predictions shows that $\mathrm{CaO}$ was the one that appeared most ( 8 times), followed by $\mathrm{P}_{2} \mathrm{O}_{5}, \mathrm{Zn}$, and $\mathrm{Cr}$ (6 times each), $\mathrm{SiO}_{2}$ (2), $\mathrm{Sr}$ (1) and $\mathrm{Fe}(1)$. Figure 3 shows the values of importance for the main variables to help predict soil properties in order to show the greater importance of $\mathrm{CaO}$ in relation to the other important variables.

In contrast to the most important variables, the ones that appeared more often in the last three positions were $\mathrm{Al}_{2} \mathrm{O}_{3}$ (7), $\mathrm{Cu}$ (4), Cl, Zr, $\mathrm{V}$ and $\mathrm{Ti}$ (3 times each), $\mathrm{K}_{2} \mathrm{O}$ (2), and $\mathrm{SiO}_{2}, \mathrm{Mn} \mathrm{Cr}, \mathrm{Fe}$ and $\mathrm{Ni}$ (1 each). It is worth noticing that $\mathrm{Al}_{2} \mathrm{O}_{3}$ may have not been an important contributor to the prediction of exchangeable $\mathrm{Al}$ since the $\mathrm{pXRF}$ obtains total element contents, including both the exchangeable $\mathrm{Al}$ and the $\mathrm{Al}$ stuck in the structure of soil minerals. However, as the study area has managed areas, the exchangeable $\mathrm{Al}$ content is quite variable (Table 2), even having little variation of total $\mathrm{Al}$ contents as obtained by $\mathrm{pXRF}$ (Table 3 ), which may have hampered the models. Similar trends can be inferred for available $\mathrm{K}$.

\section{Mapping soil properties with random forest through pXRF data}

Using random forest, which obtained better modeling and validation results than the SMLR, maps of some well predicted soil properties for the 0 to $10 \mathrm{~cm}$ layer were prepared and validated (Figure 4). The maps show that the highest contents of plant nutrients $\mathrm{Ca}$ and $\mathrm{Mg}$, higher levels of $\mathrm{OM}, \mathrm{V}, \mathrm{t}$, higher $\mathrm{pH}$ and lower exchangeable $\mathrm{Al}$ content were found in the areas of cultivated coffee, with the oldest crop being the one with better soil chemical conditions for plant development (only considering the chemical soil properties predicted here). Under eucalyptus plantation, the nutrient contents are lower, since this area was fertilized only at the moment of implantation, 5 years earlier the sampling. The areas with the lowest nutrient contents and $\mathrm{pH}$ are under native forest and native cerrado grasses, which do not present anthropogenic intervention, and reflect the high degree of weathering-leaching of these Brazilian cerrado soils (Resende et al., 2014). 


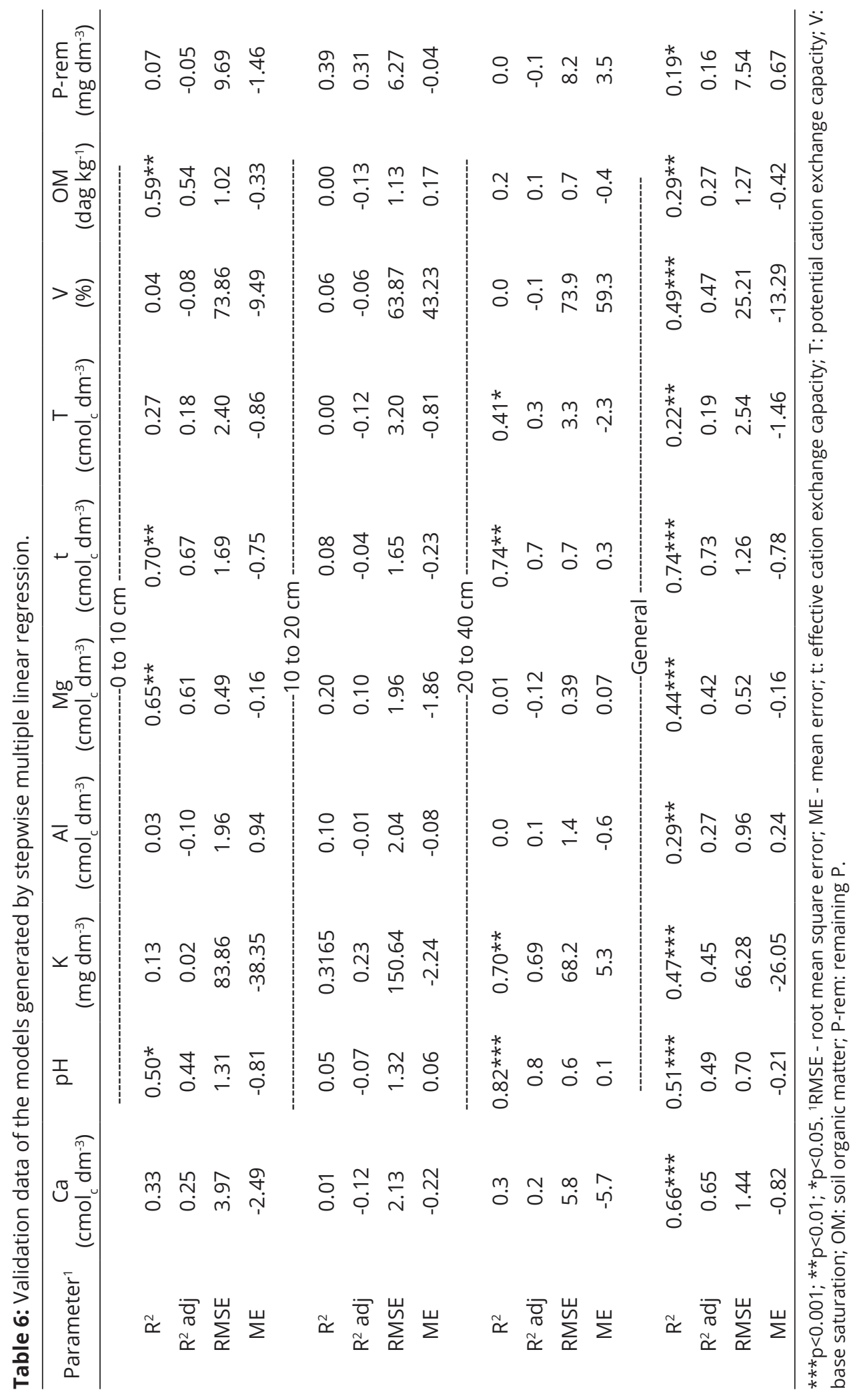




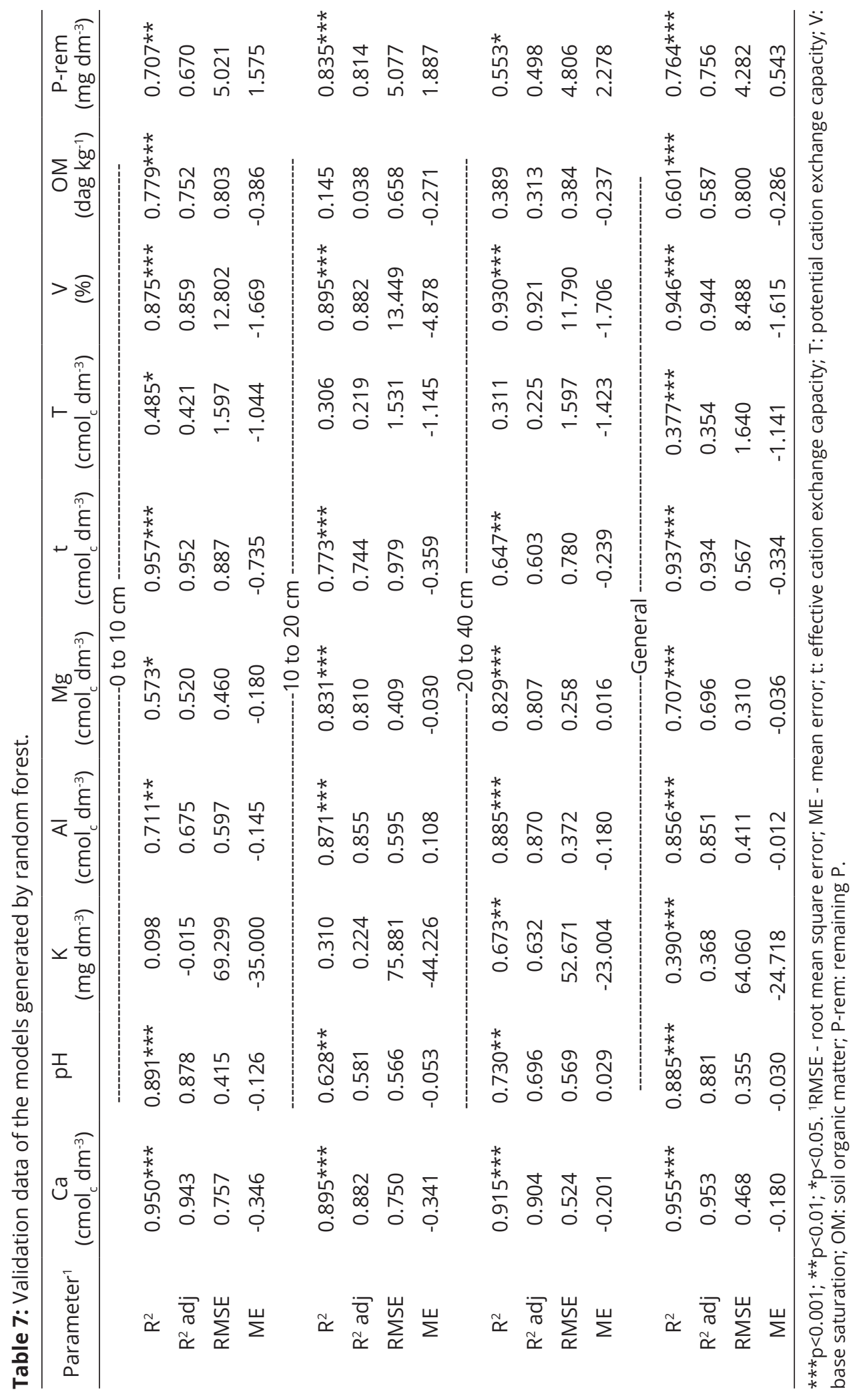


Table 8: Importance of portable X-ray fluorescence spectrometer (pXRF) variables in decreasing order to predict soil properties.

\begin{tabular}{|c|c|c|c|c|c|c|c|c|c|c|}
\hline \multirow[t]{2}{*}{$\begin{array}{l}\text { Order of } \\
\text { importance }\end{array}$} & \multicolumn{10}{|c|}{ Predicted soil property ${ }^{1}$} \\
\hline & --Al-- & --Ca-- & $--\mathrm{K}--$ & --Mg-- & --OM-- & --P-rem-- & --pH-- & --T-- & --t-- & --V-- \\
\hline 1 (most) & $\mathrm{CaO}$ & $\mathrm{CaO}$ & $\mathrm{CaO}$ & $\mathrm{CaO}$ & $\mathrm{P}_{2} \mathrm{O}_{5}$ & $\mathrm{CaO}$ & $\mathrm{CaO}$ & $\mathrm{SiO}_{2}$ & $\mathrm{CaO}$ & $\mathrm{CaO}$ \\
\hline 2 & $\mathrm{Cr}$ & $\mathrm{Cr}$ & $\mathrm{P}_{2} \mathrm{O}_{5}$ & $\mathrm{Zn}$ & $\mathrm{Zn}$ & $\mathrm{Cr}$ & $\mathrm{Zn}$ & $\mathrm{P}_{2} \mathrm{O}_{5}$ & $\mathrm{P}_{2} \mathrm{O}_{5}$ & $\mathrm{Cr}$ \\
\hline 3 & $\mathrm{Sr}$ & $\mathrm{P}_{2} \mathrm{O}_{5}$ & $\mathrm{Zn}$ & $\mathrm{Cr}$ & $\mathrm{SiO}_{2}$ & $\mathrm{Fe}$ & $\mathrm{Cr}$ & $\mathrm{Zn}$ & $\mathrm{Zn}$ & $\mathrm{P}_{2} \mathrm{O}_{5}$ \\
\hline 4 & V & $\mathrm{Zn}$ & $\mathrm{Cl}$ & $\mathrm{Sr}$ & $\mathrm{CaO}$ & $\mathrm{SiO}_{2}$ & $\mathrm{Sr}$ & $\mathrm{CaO}$ & $\mathrm{Cr}$ & $\mathrm{Zn}$ \\
\hline 5 & $\mathrm{Fe}$ & $\mathrm{Cu}$ & $\mathrm{Cr}$ & $\mathrm{P}_{2} \mathrm{O}_{5}$ & $\mathrm{Cr}$ & $\mathrm{Sr}$ & $\mathrm{P}_{2} \mathrm{O}_{5}$ & $\mathrm{Mn}$ & $\mathrm{Sr}$ & $\mathrm{Fe}$ \\
\hline 6 & $\mathrm{Zn}$ & $\mathrm{Fe}$ & $\mathrm{Cu}$ & $\mathrm{Cl}$ & $\mathrm{Mn}$ & $\mathrm{P}_{2} \mathrm{O}_{5}$ & $\mathrm{Fe}$ & $\mathrm{Sr}$ & $\mathrm{Cl}$ & $\mathrm{Sr}$ \\
\hline 7 & $\mathrm{SiO}_{2}$ & $\mathrm{Sr}$ & $\mathrm{Zr}$ & $\mathrm{Fe}$ & $\mathrm{Sr}$ & $\mathrm{Mn}$ & $\mathrm{Cu}$ & $\mathrm{Cl}$ & $\mathrm{Cu}$ & $\mathrm{SiO}_{2}$ \\
\hline 8 & $\mathrm{Al}_{2} \mathrm{O}_{3}$ & $\mathrm{SiO}_{2}$ & $\mathrm{Sr}$ & $\mathrm{Cu}$ & $\mathrm{Cl}$ & $\mathrm{Zn}$ & $\mathrm{Zr}$ & $\mathrm{Ti}$ & $\mathrm{K} 2 \mathrm{O}$ & $\mathrm{Cu}$ \\
\hline 9 & $\mathrm{~K}_{2} \mathrm{O}$ & $\mathrm{Mn}$ & $\mathrm{Ni}$ & $\mathrm{SiO}_{2}$ & $\mathrm{Ti}$ & $\mathrm{Ti}$ & $\mathrm{K}_{2} \mathrm{O}$ & $\mathrm{K}_{2} \mathrm{O}$ & $\mathrm{Mn}$ & $\mathrm{Mn}$ \\
\hline 10 & $\mathrm{P}_{2} \mathrm{O}_{5}$ & $\mathrm{Ni}$ & $\mathrm{Mn}$ & $\mathrm{Ni}$ & V & $\mathrm{Zr}$ & V & $\mathrm{Fe}$ & $\mathrm{SiO}_{2}$ & V \\
\hline 11 & $\mathrm{Mn}$ & $\mathrm{Zr}$ & $\mathrm{SiO}_{2}$ & $\mathrm{~K}_{2} \mathrm{O}$ & $\mathrm{Fe}$ & V & $\mathrm{Ni}$ & $\mathrm{Ni}$ & $\mathrm{Al}_{2} \mathrm{O}_{3}$ & $\mathrm{Ti}$ \\
\hline 12 & $\mathrm{Ti}$ & V & $\mathrm{Ti}$ & $\mathrm{Zr}$ & $\mathrm{K}_{2} \mathrm{O}$ & $\mathrm{Ni}$ & $\mathrm{Cl}$ & V & $\mathrm{Ni}$ & $\mathrm{Zr}$ \\
\hline 13 & $\mathrm{Cl}$ & $\mathrm{K}_{2} \mathrm{O}$ & $\mathrm{Al}_{2} \mathrm{O}_{3}$ & $\mathrm{Ti}$ & $\mathrm{Ni}$ & $\mathrm{K}_{2} \mathrm{O}$ & $\mathrm{Mn}$ & $\mathrm{Zr}$ & $\mathrm{Fe}$ & $\mathrm{Ni}$ \\
\hline 14 & $\mathrm{Ni}$ & $\mathrm{Ti}$ & $\mathrm{Fe}$ & V & $\mathrm{Cu}$ & $\mathrm{Al}_{2} \mathrm{O}_{3}$ & $\mathrm{SiO}_{2}$ & $\mathrm{Cu}$ & $\mathrm{Ti}$ & $\mathrm{Cl}$ \\
\hline 15 & $\mathrm{Cu}$ & $\mathrm{Cl}$ & $\mathrm{K}_{2} \mathrm{O}$ & $\mathrm{Mn}$ & $\mathrm{Al}_{2} \mathrm{O}_{3}$ & $\mathrm{Cl}$ & $\mathrm{Ti}$ & $\mathrm{Cr}$ & $\mathrm{Zr}$ & $\mathrm{K}_{2} \mathrm{O}$ \\
\hline 16 (least) & $\mathrm{Zr}$ & $\mathrm{Al}_{2} \mathrm{O}_{3}$ & V & $\mathrm{Al}_{2} \mathrm{O}_{3}$ & $\mathrm{Zr}$ & $\mathrm{Cu}$ & $\mathrm{Al}_{2} \mathrm{O}_{3}$ & $\mathrm{Al}_{2} \mathrm{O}_{3}$ & $\mathrm{~V}$ & $\mathrm{Al}_{2} \mathrm{O}_{3}$ \\
\hline
\end{tabular}

${ }^{1}$ available/exchangeable Al, Ca, K, Mg; P-rem - remaining P; OM - soil organic matter; T - potential cation exchange capacity; $\mathrm{t}$ effective cation exchange capacity; $V$ - base saturation.

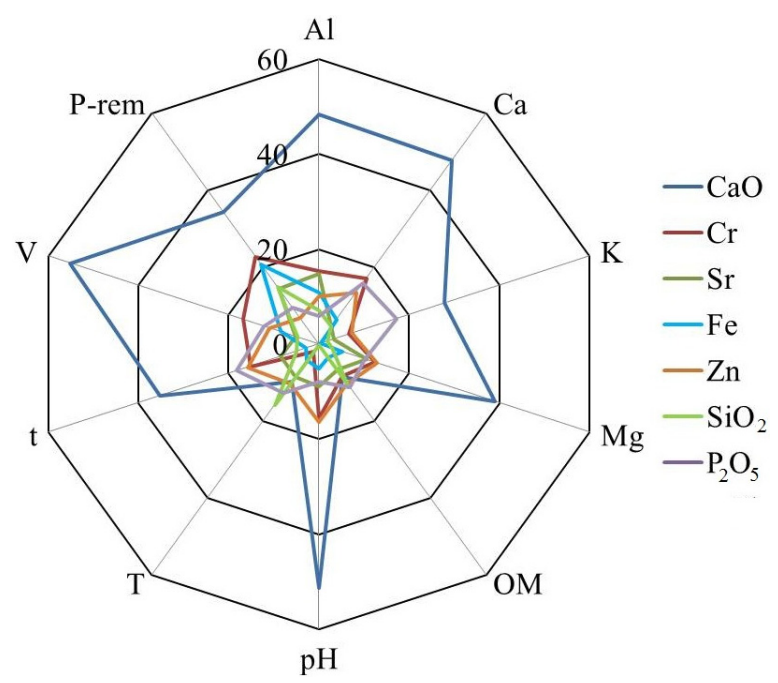

Figure 3: Most important variables of portable X-ray fluorescence spectrometer (pXRF) (importance increases from 0 to 60) for prediction of soil properties with random forest. 

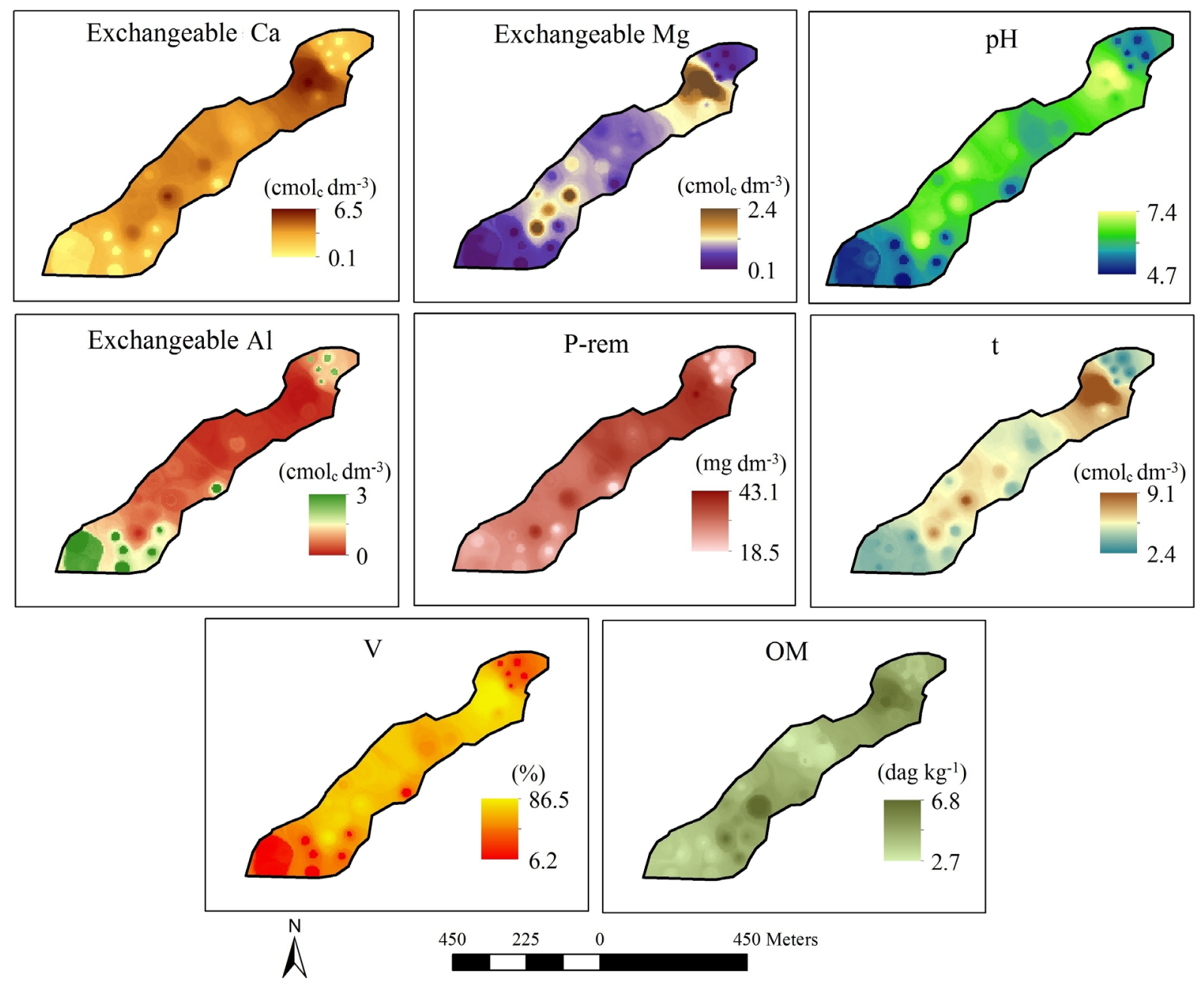

Figure 4: Maps of predicted soil properties for 0 to $10 \mathrm{~cm}$ depth spatialized with random forest; P-rem: remaining $\mathrm{P}$; t: effective cation exchange capacity; ; V: base saturation; OM: soil organic matter.

Validation of these maps with an external set of samples $(n=10)$ resulted in 1:1 graphics between predicted and observed values of the soil properties (Figure 5). For most predicted soil properties, high $\mathrm{R}^{2}$ and $\mathrm{R}_{\text {adj }}^{2}$ values were found, except for available $\mathrm{Mg}$, which had a $\mathrm{R}^{2}$ of 0.30 . For exchangeable $\mathrm{Al}\left(\mathrm{R}^{2}=0.83\right)$, P-rem $\left(\mathrm{R}^{2}=0.80\right)$, exchangeable $\mathrm{Ca}\left(\mathrm{R}^{2}=0.78\right)$ and $\mathrm{t}\left(\mathrm{R}^{2}=0.73\right)$, adequate spatialized predictions were found, followed by base saturation $\left(\mathrm{R}^{2}=\right.$ $0.67), \mathrm{OM}\left(\mathrm{R}^{2}=0.66\right)$, and $\mathrm{pH}\left(\mathrm{R}^{2}=0.54\right)$. These results indicate that, although this mapping procedure has accumulated errors, first on the spatialization of the pXRF variables by the IDW, and then during the random forest modeling and predictions, most generated soil property maps presented satisfactory accuracy. This demonstrates the potential of using pXRF as a source of variables to help predict soil properties also spatially, mainly in areas that lack continuous information in greater detail (e.g., digital elevation model and its derivatives), as it is the case of the study area of this work. In addition, by providing results quickly and inexpensively, it may favor gathering more observations (points visited) in the field and also, through predictions, reduce the number of laboratory analyses. The use of $\mathrm{pXRF}$ to improve spatial and non-spatial soil predictions was also found by Silva et al. (2016b), who used magnetic susceptibility and pXRF data, as well as continuous variables derived from digital elevation model for soil classes and properties prediction in Brazil, finding that magnetic susceptibility and pXRF data increased the models accuracy when associated with terrain data. 

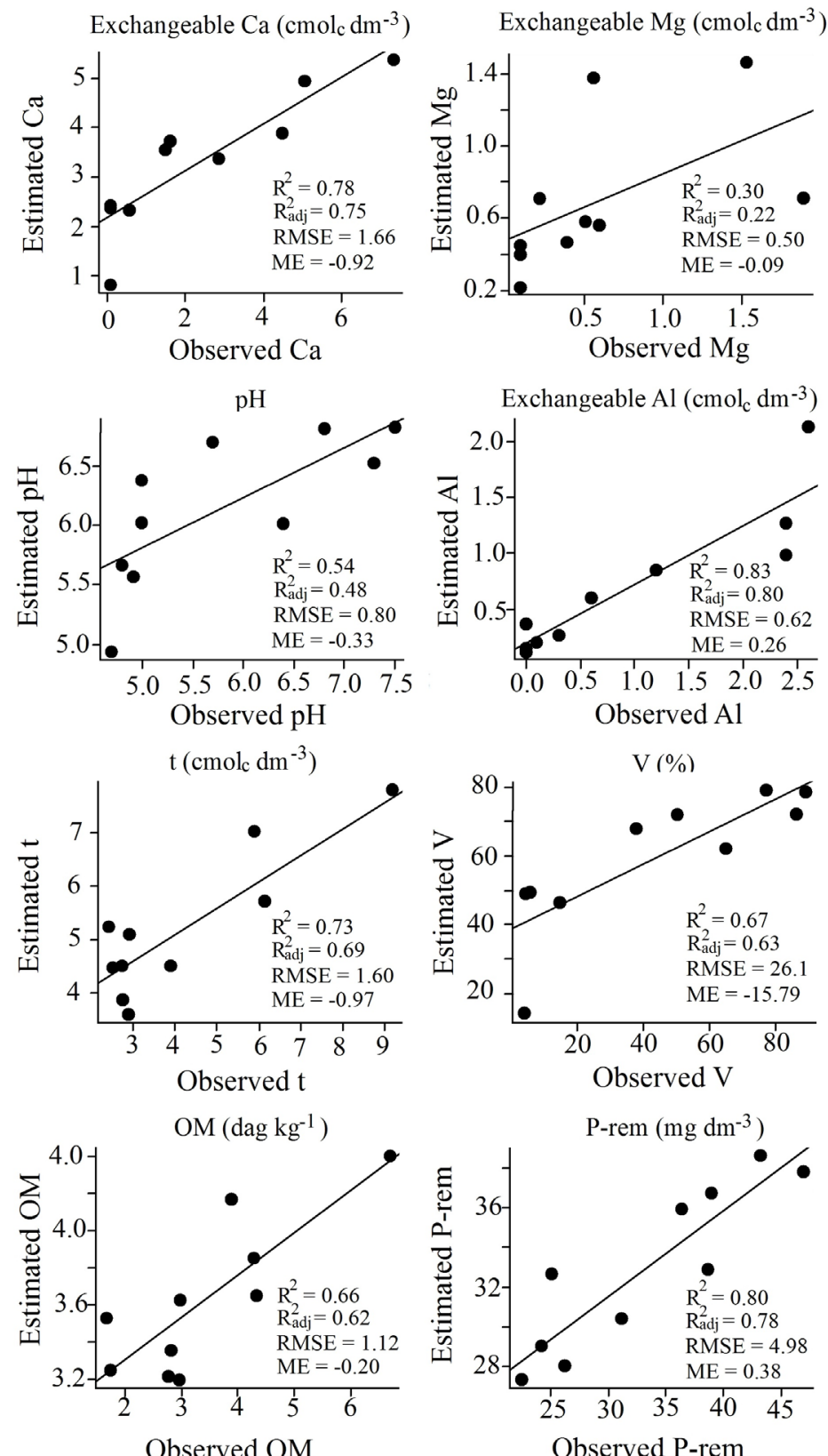

Figure 5: Plots of observed and estimated values resulted from random forest prediction of soil properties for the whole study area. $\mathrm{Ca}, \mathrm{Mg}$ and $\mathrm{Al}$ refer to exchangeable contents; $\mathrm{t}$ - effective cation exchange capacity; $\mathrm{V}$ base saturation; OM - soil organic matter; P-rem - remaining P.

Weindorf; Bakr; Zhu (2014), after presenting examples of correlations among the element contents obtained by $\mathrm{pXRF}$ and results of laboratory analysis, suggested that many works using this equipment would be performed focusing on predicting soil properties in the years to come. Here we demonstrated the potential of this equipment for predicting soil properties also in Brazilian soils, in accordance with Piikki et al. (2016), who used pXRF coupled with three other sensors to predict results of laboratory soil analyses in Kenya, observing that $\mathrm{pXRF}$ was frequently employed in good models. Sharma et al. (2014) used $\mathrm{pXRF}$ data to predict soil $\mathrm{pH}$ from linear regressions. 
Data collection through $\mathrm{pXRF}$ in this work was carried out in the laboratory; however, the use of this equipment in the field can accelerate the acquisition of data that is more difficult to be obtained, through adjustment of models with data from pXRF scanning in the field. Stockmann et al. (2016) evaluated the concentration of elements in soil profiles to infer about their parent materials using the $\mathrm{pXRF}$ in the field, in addition to making a comparison with the data obtained in the laboratory. In this way, future tests in this line of research are suggested for tropical soils, since the pXRF in association with robust algorithms can increase the amount of data on soils in Brazil both spatially and punctually, providing results rapidly, at low cost and without generation of chemical residues.

\section{CONCLUSIONS}

Soil properties such as exchangeable $\mathrm{Ca}, \mathrm{Mg}, \mathrm{Al}$, $\mathrm{pH}$, organic matter, base saturation, potential and effective CEC and P-rem could be predicted with high accuracy by random forest from the data obtained by $\mathrm{pXRF}$, surpassing the predictions made by stepwise multiple linear regression. The variables obtained by $\mathrm{pXRF}$ allowed the spatial prediction of soil properties related to soil fertility, leading to the generation of accurate maps, which demonstrates the potential of $\mathrm{pXRF}$ to be used as a source of variables to help spatial prediction of soil properties rapidly, at low cost and without generating residues.

\section{ACKNOWLEDGEMENTS}

The authors would like to thank National Council for Scientific and Technological Development (CNPQ), Coordination for the Improvement of Higher Education Personnel (CAPES) and Minas Gerais Foundation for Research Support (FAPEMIG) funding agencies for the financial support that enabled us to develop this work, and thanks to Luiz da Silva Teixeira.

\section{REFERENCES}

ADHIKARI, K. et al. Constructing a soil class map of Denmark based on the FAO legend using digital techniques. Geoderma, 214-215(2014):101-113, 2014.

ALDABAA, A. A. A. et al. Combination of proximal and remote sensing methods for rapid soil salinity quantification. Geoderma, 239:34-46, 2015.

ALVAREZ V., V. H.; FONSECA, D. M. Definição de doses de fósforo para a determinação da capacidade máxima de adsorção de fosfato e para ensaios de casa de vegetação. Revista Brasileira de Ciência do Solo, 14:49-55, 1990.
ALVAREZ V., V. H.; RIBEIRO, A. C. Calagem. In: RIBEIRO, A. C.; GUIMARÃES, P. T. G.; ALVAREZ V., V. H. (Eds.). Recomendações para o uso de corretivos e fertilizantes em Minas Gerais - $\mathbf{5}^{\circ}$ Aproximação. Viçosa: CFSEMG, 1999. p.43-60.

ARCHER, K. J.; KIMES, R. V. Empirical characterization of random forest variable importance measures. Computational Statistics and Data Analysis, 52(4):2249-2260, 2008.

BIRKELAND, P. W. Soils and geomorhology. 3rd. ed. New York: Oxford University Press, 1999. 448p.

BREIMAN, L. Random forests. Machine Learning, 45(1):5-32, 2001.

CARVALHO JUNIOR, W. de et al. Regressão linear múltipla e modelo Random Forest para estimar a densidade do solo em áreas montanhosas. Pesquisa Agropecuária Brasileira, 51(9):1428-1437, 2016.

DUDA, B. M. et al. Soil characterization across catenas via advanced proximal sensors. Geoderma, 298:78-91, 2017.

EMPRESA BRASILEIRA DE PESQUISA AGROPECUÁRIA EMBRAPA. Sistema Brasileiro de Classificação de Solos. 3rd. ed. Brasília: Embrapa, 2013. 353p.

GIASSON, E. et al. Instance selection in digital soil mapping: A study case in Rio Grande do Sul, Brazil. Ciência Rural, 45(9):1592-1598, 2015.

GRIMM, R. et al. Soil organic carbon concentrations and stocks on Barro Colorado Island - Digital soil mapping using Random Forests analysis. Geoderma, 146(1-2):102-113, 2008.

HENGL, T. et al. Mapping soil properties of Africa at $250 \mathrm{~m}$ resolution: Random forests significantly improve current predictions. Plos One, 10(6):0125814, 2015.

IOANNIDES, D. et al. A preliminary study of the metallurgical ceramics from Kition, Cyprus with the application of pXRF. Journal of Archaeological Science: Reports, 7:554-565, 2016.

JUHOS, K.; SZABÓ, S.; LADÁNYI, M. Influence of soil properties on crop yield: A multivariate statistical approach. International Agrophysics, 29(4):433-440, 2015.

LIAW, A.; WIENER, M. Classification and regression by random forest. R News, 2(December):18-22, 2002.

LIAW, A.; WIENER, M. Package “randomForest." 2015. Available in: <https://cran.r-project.org/web/packages/randomForest/ randomForest.pdf>. Access in: January, 3, 2017.

LIES, M.; GLASER, B.; HUWE, B. Uncertainty in the spatial prediction of soil texture. Comparison of regression tree and Random Forest models. Geoderma, 170:70-79, 2012. 
LOPES, A. S.; GUILHERME, L. R. G. A career perspective on soil management in the Cerrado Region of Brazil. Advances in Agronomy, 137:1-72, 2016.

MCLEAN, E. O. et al. Aluminium in soils: I. Extraction methods and magnitud clays in Ohio soils. Soil Science Society of America Proceedings, 22(5):382-387, 1958.

MENEZES, M. D. de et al. Solum depth spatial prediction comparing conventional with knowledge-based digital soil mapping approaches. Scientia Agricola, 71(4):316323, 2014.

MENEZES, M. D. de et al. Spatial prediction of soil properties in two contrasting physiographic regions in Brazil. Scientia Agricola, 73(3):274-285, 2016.

MILIĆ, M. pXRF characterisation of obsidian from central Anatolia, the Aegean and central Europe. Journal of Archaeological Science, 41:285-296, 2014.

MOTTA, P. E. F.; BARUQUI, A. M.; SANTOS, H. G. Levantamento de reconhecimento de média intensidade dos solos da região do Alto Paranaíba, Minas Gerais. 1. ed. Rio de Janeiro: Embrapa Solos, 2004. 238p.

PEINADO, F. M. et al. A rapid field procedure for screening trace elements in polluted soil using portable X-ray fluorescence (pXRF). Geoderma, 159(1-2):76-82, 2010.

PIIKKI, K. et al. Performance evaluation of proximal sensors for soil assessment in smallholder farms in Embu County, Kenya. Sensors, 16(11):1-21, 2016.

RESENDE, M. et al. Pedologia: Base para distinção de ambientes. 6th. ed. Lavras: Editora UFLA, 2014. 378p.

RODRIGUES, M. S.; CORÁ, J. E.; FERNANDES, C. Soil sampling intensity and spatial distribution pattern of soils attributes and corn yield in no-tillage system. Revista Brasileira de Ciencia do Solo, 36:599-609, 2012.

ROUILLON, M.; TAYLOR, M. P. Can field portable X-ray fluorescence ( $P X R F)$ produce high quality data for application in environmental contamination research? Environmental Pollution, 214:255-264, 2016.

SCHAETZL, R. J.; ANDERSON, S. Soil: Genesis and Geomorphology. 1st. ed. New York: Cambridge University Press, 2005. 817p.

SEVERIANO, E. D. C. et al. Potencial de uso e qualidade estrutural de dois solos cultivados com cana-de-açúcar em Goianésia (GO). Revista Brasileira de Ciência do Solo, 33(1):159-168, 2009.
SHARMA, A. et al. Characterizing soils via portable X-ray fluorescence spectrometer: 3. Soil reaction ( $\mathrm{pH})$. Geoderma, 232-234:141-147, 2014.

SHARMA, A. et al. Characterizing soils via portable X-ray fluorescence spectrometer: 4. Cation exchange capacity (CEC). Geoderma, 239:130-134, 2015.

SILVA, S. H. G. et al. Retrieving pedologist's mental model from existing soil map and comparing data mining tools for refining a larger area map under similar environmental conditions in Southeastern Brazil. Geoderma, 267:65-77, 2016a.

SILVA, S. H. G. et al. Proximal sensing and digital terrain models applied to digital soil mapping and modeling of Brazilian Latosols (Oxisols). Remote Sensing, 8:614-635, 2016b.

SOUZA, E. DE et al. Pedotransfer functions to estimate bulk density from soil properties and environmental covariates: Rio Doce basin. Scientia Agricola, 73(6):525534, 2016.

STOCKMANN, U. et al. Utilizing portable X-ray fluorescence spectrometry for in-field investigation of pedogenesis. Catena, 139:220-231, 2016.

TAGHIZADEH-MEHRJARDI, R. et al. Comparing data mining classifiers to predict spatial distribution of USDA-family soil groups in Baneh region, Iran. Geoderma, 253254:67-77, 2015.

TERRA, J. et al. Análise Multielementar de solos: Uma proposta envolvendo equipamento portátil de fluorescência de raios X. Semina: Ciências Exatas e Tecnológicas, 35(2):207214, 2014.

WALKLEY, A.; BLACK, I. A. An examination of the Degtjareff method for determining soil organic matter and a proposed modification of the chromic acid titration method. Soil Science, 37(1):29-38, 1934.

WEINDORF, D. C. et al. Characterizing soils via portable x-ray fluorescence spectrometer: 2 . Spodic and Albic horizons. Geoderma, 189-190:268-277, 2012.

WEINDORF, D. C.; BAKR, N.; ZHU, Y. Advances in portable X-ray fluorescence (PXRF) for environmental, pedological, and agronomic applications. Advances in Agronomy, 128:145, 2014.

ZHU, Y.; WEINDORF, D. C.; ZHANG, W. Characterizing soils using a portable X-ray fluorescence spectrometer: 1. Soil texture. Geoderma, 167-168:167-177, 2011. 